\title{
Порівняльна оцінка ефективності трансплантаціі стовбурових клітин пуповинної крові і парціальної резекції лівого шлуночка у хворих з дилатаційною кардіоміопатією
}

\author{
А. В. Габрієлян \\ Національний інститут хірургії та трансплантології імені О. О. Шалімова НАмН України, м. Київ

\section{Comparative estimation of the efficacy for the umbilical blood stem cells transplantation and partial resection of left ventriculus in patients, suffering dilatational cardiomyopathy}

\author{
A. V. Gabriyelyan \\ Shalimov National Institute of Surgery and Transplantology, Kyiv
}

\begin{abstract}
Реферат
Мета. Аналіз ефективності трансплантації стовбурових клітин пуповинної крові (СКПК) і парціальної лівошлуночкової вентрикулоектомії (операції Батиста) у хворих з дилатаційною кардіоміопатією (ДКМП).

Матеріали і методи. Вивчена ефективність лікування ДКМП у двох групах хворих: у 1 -й групі $(\mathrm{n}=19)$ виконували операцію Батиста, у 2-й групі ( $\mathrm{n}=22)$ - СКПК методом внутрішньовенного введення.

Результати. Встановлено, що після трансплантації СКПК у хворих з ДКМП поступово достовірно збільшується скорочувальна здатність міокарда, що проявляється збільшенням фракції викиду (ФВ) лівого шлуночка (ЛШ) 3 (19,8 \pm 7,8) до $(38,0 \pm 10,9) \%$.

Висновки. Трансплантація СКПК у хворих з ДКМП дає можливість без операції досягти достовірного приросту скорочувальної здатності міокарда, і цей ефект зберігається в строки 12 - 18 міс.

ключові слова: стовбурові клітини; операція Батиста; дилатаційна; кардіоміатія.

Abstract

Objective. Analysis of the transplantation efficacy for the umbilical blood stem cells (UBSC) and partial left-ventricular ventriculoectomy (Batista's operation) in patients, suffering dilatational cardiomyopathy (DCM).

Materials and methods. Efficacy of DCM treatment was studied in two groups of patients: in the first group $(n=19)$ Batista's operation was performed, and in the second $(n=22)$ - UBSC, using the method of intravenous injection.

Results. There was established, that after UBSC transplantation in patients, suffering DCM, the myocardium contractile capacity enhances gradually, demonstrated by the ejection fraction enhancement of the left ventriculus from (19.8 \pm 7.8$)$ to (38.0 \pm 10.9$) \%$. Conclusion. The UBSC transplantation in patients, suffering DCM, makes it possible to achieve a trustworthy growth of the myocardium contractile capacity, and this effect persists in terms $12-18$ mo.

Keywords: stem cells; Batista's operation; dilatational cardiomyopathy.
\end{abstract}

На сьогодні серцево-судинні захворювання домінують над іншими патологіями за показниками захворюваності і смертності серед населення розвинених країн, незважаючи на значні досягнення в їх профілактиці та лікуванні. Вельми актуальною є проблема хронічної серцевої недостатності (ХCH). Статистичні дані свідчать про неухильне зростання захворюваності на ХCH у всіх країнах $[1,2]$.

ДКМП як етіологічна причина виникнення ХCH за результатами європейського епідеміологічного дослідження «EuroHeart Survey HF» виявлена у 6,0\% хворих [1]. У зв'язку з низькою річною виживаністю пацієнтів (65\%) після гострого і тяжкого серцевого нападу прогноз у хворих з прогресуючою ХСН, зокрема у хворих з ДКМП, є несприятливим. Середня тривалість життя таких пацієнтів від початку захворювання становить 1,7 року - для чоловіків і 3,2 року - для жінок, а 5-річна виживаність - 25 і 38\% відповідно [1, 2].

За допомогою сучасних засобів медикаментозної терапії немає можливості змінити цей прогноз, оскіль- ки на певній стадії хвороби вони практично втрачають свою ефективність. Протягом п'яти років за даними «Framingham study» від початку захворювання на тлі медикаментозної терапії помирають 42\% жінок і 62\% чоловіків [2].

Недостатня ефективність медикаментозної терапіі ДКМП спонукала дослідників до пошуку хірургічних методів лікування цього захворювання і його ускладнень.

До останнього часу єдиним засобом, що дає можливість збільшити тривалість життя хворих з ДКМП і поліпшити їх функціональний стан, вважали трансплантацію серця.

У провідних кардіохірургічних центрах світу на частку таких хворих припадає понад 50\% реципієнтів [3]. У той же час згідно з даними організації «EUROTRANSPLANT» за 2016 р. частка хворих, які перебувають у листі очікування та очікують донорське серце більше 24 міс, становить 34,6\%, а частка хворих, які очікують серце більше року, 56,8\% [4]. Дефіцит донорських органів, висока вартість трансплантації серця і подальшої імуносупресивної те- 
рапії, а також проблеми правового характеру в ряді країн спонукають до пошуку «альтернативних» методів хірургічного лікування ДКМП, а також інших ефективних методів лікування, результатами яких є продовження періоду очікування донорського серця, зменшення проявів ХCH і уникнення ускладнень з боку інших органів і систем [3].

Як хірургічна процедура для заміни або відстрочки трансплантації серця у пацієнтів з ДКМП запропонована операція парціальної резекції ЛШ з наступним його ремоделюванням, також відома як операція Батиста [5]. Через високу операційну летальність і частоту повернення проявів серцевої недостатності ця операція не набула широкого поширення, хоча ії досі активно застосовують і вдосконалюють у ряді світових клінік [6].

Останнім часом дедалі більше дослідників приділяють пильну увагу вивченню можливості застосування стовбурових клітин у комплексному лікуванні хворих з ДКМП $[7,8]$. Отримані експериментальні й клінічні дані дуже обнадійливі [9-11].

Мета дослідження: проаналізувати ефективність трансплантації СКПК і парціальної резекції ЛШ (операції Батиста) у хворих з ДКМП.

\section{Матеріали і методи дослідження}

У дослідження включено 41 пацієнта. Всіх пацієнтів розподілили на дві групи. В 1-шу групу увійшли 22 пацієнти, яким виконали трансплантацію СКПК, у 2-гу - 19 пацієнтів, яким виконали парціальну резекцію ЛШ (операцію Батиста).

Всім пацієнтам проводили клінічне та інструментальне обстеження за розробленою програмою, яка включала загальноклінічні дослідження з оцінкою функціонального класу за NYHA, електрокардіографію (ЕКГ), холтерівське моніторування, ехокардіографію (ЕХОКГ) з визначенням секторальної скоротливості міокарда, коронарографію.

\section{Таблиця 1. Клінічна характеристика пацієнтів}

\begin{tabular}{|c|c|c|}
\hline \multirow{2}{*}{ Показник } & \multicolumn{2}{|c|}{ Групи } \\
\hline & 1-ша $(n=22)$ & 2-га $(n=19)$ \\
\hline \multicolumn{3}{|l|}{ Стать } \\
\hline чоловіки & 22 & 19 \\
\hline жінки & - & - \\
\hline Вік, роки $(\bar{x} \pm m)$ & $45,7 \pm 12,1$ & $42,3 \pm 16,9$ \\
\hline \multicolumn{3}{|l|}{ АТ систолічний, } \\
\hline кПа $(\bar{x} \pm m)$ & $14,4 \pm 2,4$ & $11,9 \pm 1,5$ \\
\hline мм рт. ст. $(\bar{x} \pm m)$ & $108,1 \pm 17,9$ & $89,7 \pm 11,2^{*}$ \\
\hline \multicolumn{3}{|l|}{ АТ діастолічний, } \\
\hline кПа $(\bar{x} \pm m)$ & $10,0 \pm 1,8$ & $8,3 \pm 1,1$ \\
\hline мм рт. ст. $(\bar{x} \pm m)$ & $75,0 \pm 13,2$ & $62,5 \pm 8,9$ \\
\hline Набряки абс.(\%) & $22(100 \%)$ & $19(100 \%)$ \\
\hline Задишка у спокої абс.(\%) & $5(22,7 \%)$ & $5(26,3 \%)$ \\
\hline ЧСС, за 1 хв $(\bar{x} \pm m)$ & $89 \pm 13,7$ & $103 \pm 18,8$ \\
\hline Інтервал $\mathrm{p}-\mathrm{Q},(\overline{\mathrm{x}} \pm \mathrm{m})$ & $0,20 \pm 0,1$ & $0,21 \pm 0,02$ \\
\hline \multicolumn{3}{|l|}{ NYHA } \\
\hline III абс.(\%) & $6(27,3 \%)$ & $3(15, \%)$ \\
\hline IV абс.(\%) & $16(73,7 \%)$ & $16(84,2 \%)$ \\
\hline \multicolumn{3}{|c|}{$\begin{array}{ll}\text { Примітка. } & \text { АТ - артеріальний тиск; чСС - частота } \\
& \text { серцевих скорочень; }{ }^{*}-\text { p }<0,05\end{array}$} \\
\hline
\end{tabular}

Всі пацієнти до госпіталізації в клініку Інституту отримували сучасну медикаментозну терапію, яка, однак, була малоефективною. Всі пацієнти з огляду на клініко-функціональні показники були кандидатами на трансплантацію серця і перебували в листі очікування. В дослідження не включали пацієнтів із серцевою недостатністю клапанного генезу, ішемічною хворобою серця, гострим міокардитом, кардіоміопатією, зумовленими вродженими вадами серця, із супутніми хронічними дегенеративними системними захворюваннями, віком старше 65 років, із неврологічними захворюваннями та хронічною нирковою або легеневою недостатністю, а також дітей і підлітків. Для досягнення однорідності досліджуваних груп у дослідження також не включали хворих із недостатністю мітрального клапана II-IV ступеня, яким у ході виконання операції Батиста було необхідно додаткове втручання на мітральному клапані.

Всі учасники дослідження підписували інформовану згоду та протокол дослідження, схвалений комітетом 3 біоетики

За основними клініко-функціональними показниками аналізовані групи були ідентичні (табл. 1).

За даними ЕХОКГ (табл. 2) більші об'єми порожнин серця виявлені у пацієнтів 2-ї групи, хоча різниця показників недостовірна, а ФВ ЛШ була достовірно нижче у пацієнтів 1-ї групи.

Під час коронарографії ні в 1-й, ні в 2-й групі не було виявлено гемодинамічно значущих звужень коронарних артерій.

Трансплантацію СКПК проводили за допомогою внутрішньовенного крапельного введення клітинного препарату «Кріоконсервована пуповинна кров людини». Кількість ядровмісних клітин у введеному препараті становила від 0,89 × $10^{9}$ до 0,95 × 109, кількість мононуклеарів - від 0,486 × $10^{9}$ до 0,520 × 109, CD 34+ клітин - не менш $1,0 \pm 0,01 \times 10^{3}$.

Парціальну резекцію ЛШ виконували з використанням штучного кровообігу в умовах помірної гіпотермії (34 $\left.35^{\circ} \mathrm{C}\right)$. У 14 хворих хірургічні маніпуляції виконали на фібриляції шлуночків без затискання аорти, у 5 - в умовах кардіоплегічної зупинки серця. Середня тривалість пер-

Таблиця 2. Початкові показники ЕХОКГ ( $\overline{\mathbf{x}} \pm \mathrm{m})$

\begin{tabular}{|lcc|}
\hline \multirow{2}{*}{ Показник } & \multicolumn{2}{c|}{ Групи } \\
\cline { 2 - 3 } КДО, мл & $258,3 \pm 101,2$ & 2-га $(\mathrm{n}=19)$ \\
\hline КДІ & $123,1 \pm 43,0$ & $306,7 \pm 55,3$ \\
\hline КСО, мл & $187,4 \pm 47,2$ & $135,0 \pm 39,0$ \\
\hline КСІ & $99,3 \pm 39,4$ & $95,1 \pm 39,9$ \\
\hline УО, мл & $47,2 \pm 22,2$ & $68,8 \pm 28,2$ \\
\hline СТЛА & $46,4 \pm 16,6$ & $57,5 \pm 12,2$ \\
\hline ФВ, \% & $19,8 \pm 7,8^{*}$ & $29,7 \pm 9,2$ \\
\hline Примітка. & КДО-кінцево-систолічний об'єм; \\
& КДІ- кінцево-діастолічний індекс; \\
& КСО-кінцево-систолічний об'єм; \\
& КСІ-кінцево-систолічний індекс; \\
& УО-ударний об'єм; \\
& СТЛА-систолічний тиск в легеневій артерії; \\
& *р=0,0075 \\
\hline
\end{tabular}


фузії - $(150,5 \pm 46,5)$ хв. Висікали клапоть передньо-бічної стінки ЛШ у міжсудинній зоні з наступною пластикою ЛШ, а також пластикою міжпапілярного простору П-подібними швами.

\section{Результати}

Середній період спостереження склав $(16,3 \pm 5,8)$ міс. У пацієнтів після операції Батиста достовірно зменшився об'єм ЛШ з $(306,7 \pm 55,3)$ до $(258,2 \pm 5,1)$ мл $(\mathrm{p}=0,031) 3$ одночасним збілышенням ФВ з $(29,7 \pm 9,0)$ до $(35,6 \pm 8,3) \%$ $(\mathrm{p}=0,02)($ рис. 1).

У хворих після трансплантації СКПК ФВ поступово збільшувалась і досягала свого піку на 12-му міс спостереження - $(38,0 \pm 10,9) \%(p=0,021)$. Надалі спостерігали тенденцію до зниження ФВ і на 18-му міс вона становила $(29,0 \pm 8,1) \%$, що було вище вихідного рівня (рис. 2). Безпосередньо після операції Батиста ФВ достовірно збільшувалась, а далі спостерігали тенденцію до ії зниження починаючи з 6-го міс, і на 18-му міс спостереження ії значення повернулося практично до початкового - $(30,0 \pm 5,8) \%$.

Аналіз динаміки змін об'єму ЛШ (рис. 3) показав, що трансплантація СКПК істотно не впливала на його розміри, хоча КдО ЛШ знизився 3 (272,0 \pm 79,9) до $(258,2 \pm$ $56,1)$ мл, але різниця показників була недостовірна. Після операції Батиста КДО ЛШ достовірно зменшився, однак під час подальшого спостереження відбувалась його повторна дилатація.
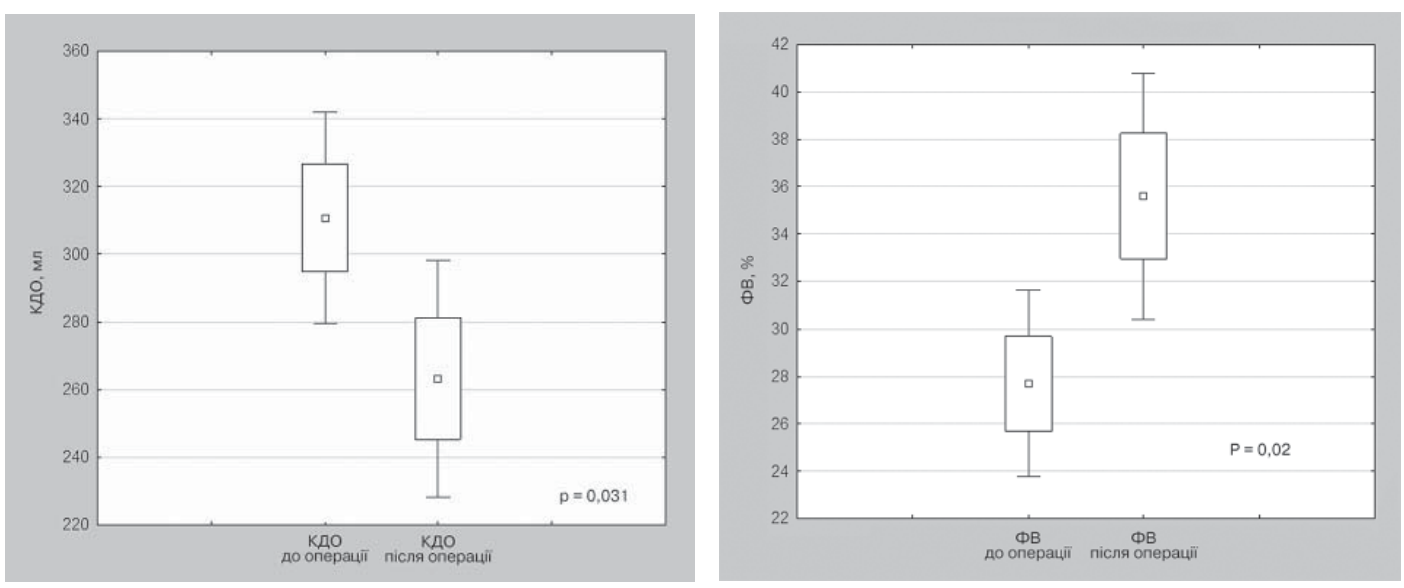

Puc. 1.

Безпосередні результати після операиї̈ Батиста за даними ЕХОКГ.

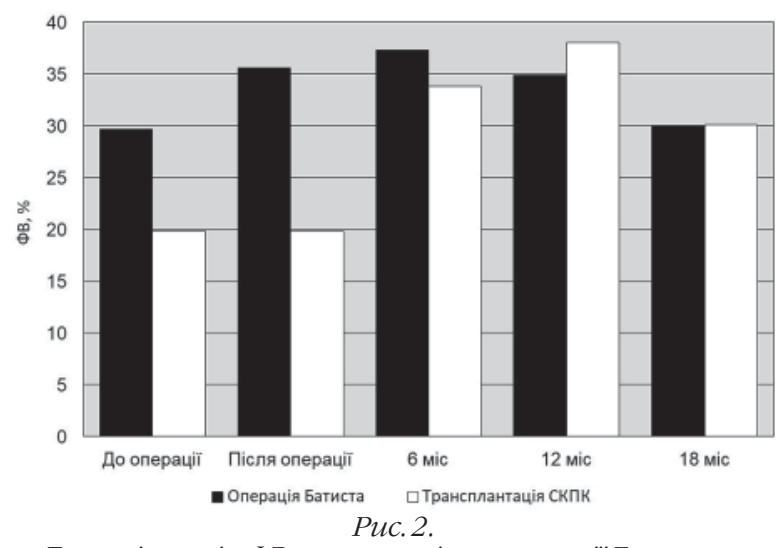

Динаміка змін ФВ у хворих після операиї Батиста та трансплантацї̈ СКПК за даними ЕХОКГ.
Безпосередньо після операції Батиста померло 3 (15,7\%) хворих. Через рік після операції помер 1 пацієнт, через 16 міс - ще 1. Загальна летальність за весь період спостереження з урахуванням операційної становила 26,3\%.

Безпосередньо після трансплантації СКПК ніхто із пацієнтів не помер. За період спостереження в цій групі помер 1 хворий через 5 міс після трансплантації СКПК. Летальність становила 4,5\%.

На основі аналізу виживаності з використанням методу Каплана - Мейєра (рuс. 4) отримано кращий показник у хворих 1-ї групи, яким виконали трансплантацію СКПК (89,3\%), порівняно з хворими 2-ї групи, яким виконали операцію Батиста (68,4\%).

\section{Обговорення}

Дилатаційна некоронарогенна кардіоміопатія є поліетіологічним синдромом, що супроводжується прогресуванням тяжкої серцевої недостатності.

Незважаючи на значну кількість досліджень та величезний клінічний досвід, медикаментозна терапія ДКМП у даний час є малоефективною і не запобігає розвитку тяжкої серцевої недостатності. Можливості хірургічних методів лікування цього захворювання, крім трансплантації серця, також обмежені. Запропонована в 1997 р. Р. Батиста парціальна резекція ЛШ мала стати альтернативою трансплантації серця. Операція полягала у висіченні клаптя з дилатованого ЛШ, щоб зменшити його об'єм до оптимально-

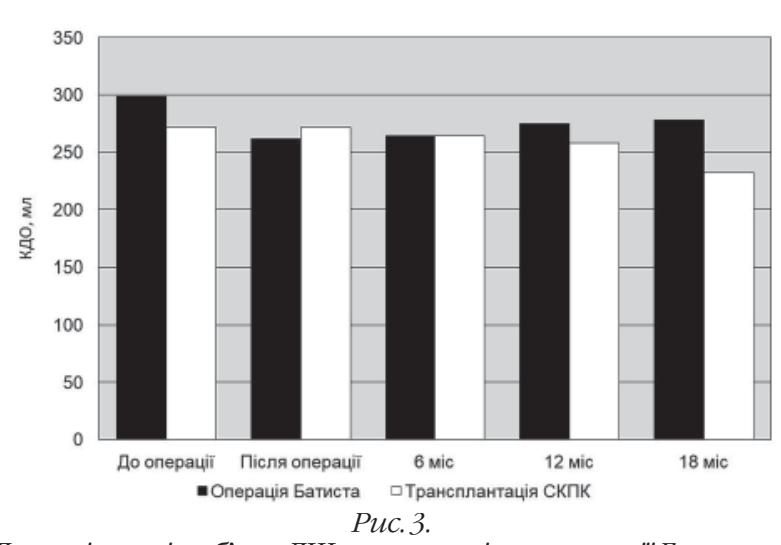

Динаміка змін об'єму ЛШ у хворих після операцї̈ Батиста та трансплантацї̈ СКПК за даними ЕХОКГ. 


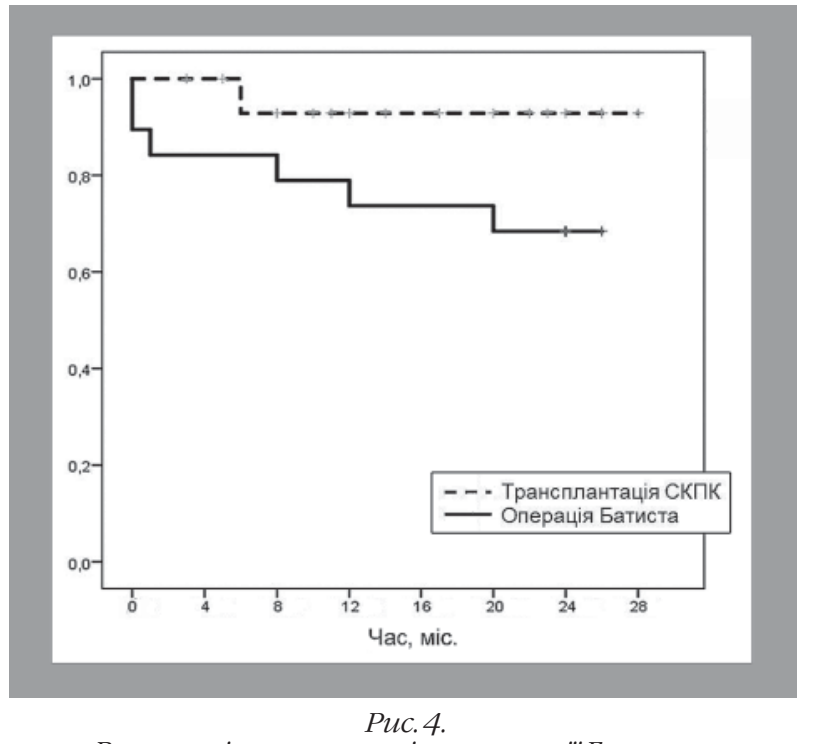

Виживаність хворих після операиї̈ Батиста і трансплантащї СКПК (за методом Каплана - Мейєра).

го і поліпшити скоротливу функцію. Після перших обнадійливих результатів склалося загальне клінічне враження, що операція може служити мостом до трансплантаціі серця. Однак через високу операційну летальність, високу частоту повернення серцевої недостатності в останнє десятиліття інтерес до цієї операції помітно зменшився. Госпітальна летальність хворих з ДКМП після операціі Батиста коливається від 18 до 25\%, виживаність протягом одного року - від 82 до 86\%, протягом 5 років - від 41 до 49\% в залежності від вихідної тяжкості застійної серцевої недостатності [1, 2].

У той же час ряд авторів продовжують активно застосовувати операцію, пропонуючи нові ії модифікації. J. S. Domingues і співавтори [6] проаналізували 206 публікацій у 22 професійних періодичних виданнях, виділених в базах даних Scopus, MEDLINE, ScienceDirect, OneFile, Web of Science, Scielo та PubMed. Японія виявилась лідером щодо публікацій - 46,5\%, на другому місці була Німеччина $20,9 \%$. Автори широко обговорюють питання зони резекції ЛШ для зменшення шкідливого ефекту на міокард, необхідності виконання парціальної резекції у поєднанні з наближенням папілярних м'язів.

Особливої уваги заслуговує питання необхідності корекції мітральної недостатності у хворих з ДКМП. В наше дослідження ми включили хворих, у яких ступінь мітральної недостатності не перевищував 1,5+, тобто не було потреби в корекції. За 24 міс спостереження не виявлено збільшення ступеня мітральної недостатності ні у хворих, яким була виконана операція Батиста, ні у хворих після трансплантації СКПК. У літературі, проте, звертається увага, що у хворих з ДКМП після корекції мітральної недостатності у разі ії необхідності безпосередні та віддалені результати кращі, ніж у хворих, яким таку корекцію не виконували, при цьому перевагу віддають пластичним втручанням на мітральному клапані $[3,11,12]$. Це виправдовує виконання операції Батиста з вираженою мітральної недостатністю. Трансплантація СКПК у таких хворих малоефективна, тому що можливе збільшення скоротли- вої функції ЛШ призведе до збільшення ступеня мітральної недостатності.

Операція Батиста дає можливість достовірно зменшити об'єм ЛШ, створити ефективну його геометрію, що приводить до збільшення ФВ. Однак ефект даної процедури тимчасовий. Пов'язано це з тим, що операція не усуває причин, які спочатку призвели до дилатації ЛШ, і після операції він знову поступово дилатується. Трансплантація СКПК не приводить до достовірного зменшення об'єму ЛШ. Помітне зменшення відбувається лише в термін до 1 року після трансплантації. У той же час достовірно збільшується скоротлива здатність міокарда, зменшуються симптоми серцевої недостатності, поліпшується відповідь на медикаментозну терапію. Так само, як і після операції Батиста, позитивний ефект після трансплантації СКПК має тимчасовий характер. Тому, як і операцію Батиста, трансплантацію СКПК можна розглядати не стільки як самостійний метод, скільки як один із методів у комплексному лікуванні хворих з ДКМП, що дає змогу дочекатися донорського органа, тобто це міст до трансплантації.

Отримані під час проведеного дослідження дані показали, що результати трансплантації СКПК схожі з результатами операції Батиста. У той же час летальність у групі пацієнтів після трансплантації СКПК була меншою, а виживаність за період спостереження - вищою, що дає підстави вважати цей метод кращим у лікуванні хворих з ДКМП.

\section{Висновки}

1. Трансплантація СКПК в середньостроковому періоді спостереження має результати, порівнянні за функціональними даними з результатами операції Батиста. У разі ii застосування немає необхідності у виконанні травматичного втручання, також вона не супроводжується операційною летальністю. Виживаність за період спостереження до 2 років вища у хворих, яким виконана трансплантація СКПК.

2. Трансплантацію СКПК у хворих з ДКМП без вираженої мітральної недостатності можна розглядати як альтернативу хірургічному втручанню. Віддалені результати і виживаність пацієнтів у терміни понад 2 роки потребують подальшого вивчення.

\section{References}

1. Shumakov DV, Shurigin SN, Timerbaev AV. Sovremennye hirurgicheskie metody lechenija dilatacionnoj kardiomiopatii. 2009;(4):92-6.

2. Rizun LI, Koval' GD, Van EJu, Hovrin VV, Fedorov DN, Klimenko VS, et al. Diagnosticheskij algoritm i taktika vedenija bol'nyh s sindromom dilatacionnoj kardiomiopatii. Bukovynskyi medychnyi visnyk. 2016;2(78):130-7.

3. Suma H. Partial Left Ventriculectomy. Circ J. 2009; Suppl A;A19 A22. https://doi.org/10.1253/circj.CJ-08-1075. doi: 10.1111/j.15408191.2005.00155a.x.

4. Eurotransplant International Foundation. Annual report 2016 [Internet] Leiden; Eurotransplant Foundation, 2016; Available from: http://www.eurotransplant.org $/ \mathrm{cms} /$ mediaobject.php?file=Eurotransplant $+\mathrm{JV}+\mathrm{PDF}$.pdf.

5. Batista RJ, Verde J, Nery P, Bocchino L, Takeshita N, Bhayana JN, et al. Partial left ventriculectomy to treat end-stage heart disease. Ann Thorac Surg. 1997;64(3):634-8.https://doi.org/10.1016/S0003-4975(97)00779-0

6. Domingues JS, Vale MP, Barbosa MP. Partial left ventriculectomy: have well-succeeded cases and innovations in the procedure been observed in the last 12 years? Braz J Cardiovasc Surg. 2015;30(5):579-85. doi: 10.5935/1678-9741.20150061. 
7. Strauer BE, Brehm M, Schannwell CM. The therapeutic potential of stem cells in heart disease. Cell Prolif. 2008;41(Suppl. 1):126-45. doi:10.1111/ j.1365-2184.2008.00480.x

8.Roura S, Gálvez-Montón C, Bayes-Genis A. Umbilical cord bloodderived mesenchymal stem cells: New therapeutic weapons for idiopathic dilated cardiomyopathy? International Journal of Cardiology. 2014;(177):809-18 http://dx.doi.org/10.1016/j.ijcard.2014.09.128.

9. Zhao XF, Xu Y, Zhu ZY, Gao CY, Shi YN. Clinical observation of umbilical cord mesenchymal stem cell treatment of severe systolic heart failure. Genetics and Molecular Research. 2015,14(2):3010-17. doi http:// dx.doi.org/10.4238/2015.

10. Hollweck T, Hagl C, Eissner G. Mesenchymal stem cells from umbilical cord tissue as potential therapeutics for cardiomyodegenerative dis- eases - a review. International Journal of Molecular and Cellular Medicine. 2012;1(3):119-32. PMCID: PMC3920507.

11. Medhekar SK, Shende VS, Chincholkar AB. Recent stem cell advances: Cord Blood and Induced Pluripotent Stem Cell for Cardiac Regeneration- a Review. International Journal of Stem Cells. 2016;9(1):2130. http://dx.doi.org/10.15283/ijsc.2016.9.1.21.

12. Morimoto K, Kuroda H, Ono K, Miyasaka S, Shiraya S, Kobayashi F, et al. Modified Batista Procedure for Idiopathic Dilated Cardiomyopathy: Report of a Case. World Journal of Cardiovascular Surgery. 2017;(7): 32-40. doi: 10.4236/wjcs.2017.73005. 